\title{
Endo beta 1-3(4) glucanase supplementation of barley based diet and its effects on some hematological parameters of common carp (Cyprinuscarpio)
}

\author{
Meysam Mohammadbeygi, Mohammad Reza Imanpour, Vahid Taghizadeh and Ali Shabani \\ Department of Fishery, Faculty of Fisheries and Environment, Gorgan University of Agricultural Science and Natural \\ Resources, Gorgan, Iran.
}

Accepted 29 November, 2012

\begin{abstract}
Carbohydrates are cheap energy sources in animal nutrition. These stuffs are rich in anti-nutrient factors which affect the animal physiological performance. Some main compositions are called nonstarch polysaccharides which mainly composed of arabinoxylans (that is, in wheat, triticale and rye) and beta glucanases (that is, in barley and oats). In this study, 90 fish in three treatments (30 fish treatment $^{-1}$ ) and in triplicate itself (each replicate contains $10 \mathrm{fish}, 50 \mathrm{~L}$ glass aquarium ${ }^{-1}$ ) fed by enzyme treated diets in 3 levels of $0 \%$ as control, $0.1 \%$ and $0.5 \%$ for 8 weeks. Enzyme supplementation at the level of $0.1 \%$ increased blood parameters such as blood sugar, cholesterol and triglyceride but decreased total protein and uric acid $(P<0.05)$. In term of hematological parameters, best performance was evaluated for enzyme treatment at the level of $0.5 \%$. All parameters such as white blood cells (R.B.Cs), red blood cells (R.B.Cs), hemoglobin and hematocrit in this level $(0.5 \%)$ was higher than other treatments $(P<0.05)$. The aim of this study was to evaluate the effects of purified $b$-glucanase on someblood parameters of common carp (Cyprinus carpio) fed on barley based diet. Authors suggest that beta-glucanase addition in aqua-feeds based on barley can be useful for fish health and may be as immunity stimulator.
\end{abstract}

Key words: Non-starch polysaccharides, glucose, cholesterol, triglycerides, hematocrit.

\section{INTRODUCTION}

Common carp (Cyprinus carpio) is one of common cultural species in all around the world. Even though there are plenty of documents in carp nutrition but there should be some studies to improve this field. In some cases, researchers replaced some diets with others or added some biological agent into diet to achieve better feed conversion ratio (FCR) and better growth either, but some of them succeed (Bogut et al., 1998; Yanbo and Zirong, 2006) and some did not (Shabir et al., 2003; Siddhuraju and Becker, 2001). Carbohydrates are cheap energy source for animal feed but these materials are composed of some anti-nutritional factors that influence the animal performance. The endosperm cell walls of

\footnotetext{
*Corresponding author. E-mail: meysambeygi@gmail.com.
}

wheat, barley, rye, oats and so many cereals have these anti-nutritive properties. One of the most important antinutrients exists in animal diets are non-starch polysaccharides (NSPs) which divided into two main groups: pentoses (arabinoxylans and xylans) and hexoses. It has been clearly demonstrated that the primary mechanism of the anti-nutritional effects of the soluble NSP activity is related to their viscous properties and hence the presence of soluble beta-glucans in barley is one of the major causes of growth depression and poor feed conversion ratio in monogastric animals (Mathlouthi et al., 2002).

Fishes, like other non-ruminant animals, do not produce digestive enzymes which degrade the cell wall; so they cannot storage NSPs found in various concentrations of the plant materials used for animal feeding (Knudsen, 1997). Dietary fiber components can interfere 
Table 1. Barley based diet formulation.

\begin{tabular}{lc}
\hline Feed stuff (\%) & Quantity (\%) \\
\hline Barley flour & 52 \\
Fish meal & 33 \\
Fish oil & 12 \\
Vitamin and mineral supplementary ${ }^{*}$ & 2 \\
Chromium oxide $\left(\mathrm{Cr}_{2} \mathrm{O}_{3}\right)$ & 1 \\
Approximate composition of feed & \\
Dry matter (\%) & 90.07 \\
Crude protein (\%) & 31.6 \\
Gross energy (KCal/kg) & 3369.12 \\
Ash (\%) & 4.94 \\
Lipid (\%) & 3.864 \\
Crude fiber (\%) & 0.198 \\
Lysine & 2.11 \\
Methionine & 0.77 \\
\hline
\end{tabular}

*Vitaminet water soluble multivitamin plus trace elements manufactured by Damloran Pharma Co. Birjand, Iran. Ingredients per each gram: Vitamin A: 10000 IU; Vitamin D3: 3000 IU; Vitamin E: $3 \mathrm{mg}$; Vitamin B1: $2 \mathrm{mg}$; Vitamin B2: $2 \mathrm{mg}$; Vitamin B6: $1 \mathrm{mg}$; Vitamin K3: $2 \mathrm{mg}$; Nicotinamide: $15 \mathrm{mg}$; Calcium pantothenate: 5 $\mathrm{mg} ; \mathrm{Cu} 2+: 3 \mathrm{mg} ; \mathrm{Fe}^{2+}: 12 \mathrm{mg} ; \mathrm{Zn}^{2+}: 15 \mathrm{mg} ; \mathrm{Mn}^{2+}: 25 \mathrm{mg}$.

with the digestion and absorption processes in the small intestine and the production of digestive enzymes (Graham et al., 1988). The chemical composition of barley varies considerably with variety, growing conditions and year (Bach Knudsen et al., 1987b) which contain implications for the nutritive value (Bach Knudsen et al., 1987a).

The fiber consists of several cell walls. These cell walls are formed from oriented reinforcing semi-crystalline cellulose micro fibrils embedded in a hemicellulose-lignin matrix of varying composition (Kalia et al., 2011). The main DF components of the cell wall of barley are cellulose, arabinoxylans and mixed-linked beta 1-3(4) Dglucan (beta- glucan) (Jensen et al., 1998). Beta-glucan is a linear homo-polymer of D-glucose residues which are linked through beta-1, 3 glycosidic bonds in the main chain. This polysaccharide, comprising the highest percentage of the fungal cell walls, has a major role in providing the cell wall with rigidity and protection. This is generally achieved through the assistance of other cell wall components, such as chitin and different proteins (Bahramsari et al., 2007).

As known, NSPs are the most anti-nutritive components that are found in the cell wall of cereals. There are some ways to reduce these materials and improve diet's nutritional value such as pelleting (Rowe et al., 1999), extrusion (Herstad and McNab, 1975), soaking (Fry et al., 1958), Gamma irradiation (Campbell et al., 1986) and enzyme treatment (Kaiser, 1999). Enzymes are biological products that catalyze the biochemical reactions involved in cell life. Enzymes are proteins of high molecular weight (between 10,000 and 500,000
Daltons), precipitated by alcohol, acetone, and ammonium sulphate. Like all proteins, they are sensitive to the physicochemical environment, variations in which may modify their activity (Sabatier and Fish, 1996). With enzyme supplementation the effect of varying betaglucan level is minimal. A series of experiments were conducted to study the effects of enzyme supplementation of diets containing high levels of a local variety of barley on the performance of broiler chickens (Hesselman and Thomke, 1982). The purpose of this present study was to study the effects of enzyme addition to diets based on locally grown barley and fed to common carp (C. carpio) in the form of pellets.

\section{MATERIALS AND METHODS}

\section{Fishes and experimental conditions}

This experiment carried out at a $3 \times 3$ factorial as a complete randomized design in the fisheries research center of Gorgan University of Agriculture Sciences \& Natural Resource, Gorgan, Iran. Fishes brought from Institute of Aquaculture of the Marjani and transferred to research center and exposed in 2 ppt salt bath before introducing to aquaria. 90 individuals of common carp (C.carpio) with average weight of $13.46 \pm 0.17 \mathrm{~g}$ distributed into 9 glass aquaria groups containing 10 fish per group which divided into 3 subgroups. Aquaria filled up to 50 liter, temperature adjusted to 25 $\pm 1^{\circ} \mathrm{C}$ and water aerated as well as possible. Diets prepared and fishes fed by $3.5 \%$ of wet body weight twice a day at $8 \mathrm{AM}$ and 8 PM (Ogino, 1980). The method for feed preparation and enzyme addition are described in the next sections. Initial diet (experimental diet without enzyme) used for first week of fishes adaptation to new experimental situation and after that, fishes fed by experimental diets (Table 1) for 8 weeks of trial. No fish died during experiment. Fish were weighed every 2 weeks and the amount of diet fed was adjusted accordingly.

\section{Enzyme preparation}

Beta-glucanase (Endo beta 1-3(4) D-glucanase, EC 3.2.1.6) is in 16th glucanohydrolase family which degrades the carbohydrate polymers into its component residues by breaking the betaglycosidic bonds (Bahramsari et al., 2007). Enzyme added to diets by dissolving in buffer solution (Citrate-Phosphate buffer, $\mathrm{pH}=4.8$ ). For making a Citrate-Phosphate buffer $(\mathrm{pH}=4.8), 252 \mathrm{ml}$ of $0.1 \mathrm{~N}$ citric acid (Merck, Germany) and $248 \mathrm{ml}$ of $0.2 \mathrm{~N}$ dibasic sodium phosphate were mixed (Merck, Germany) in $1000 \mathrm{ml}$ distilled water according to manual (Colowick and Kaplan, 1955). As resulted in some researches, optimum conditions of this enzyme related to $\mathrm{pH}$, temperature and even some other factors such as wetness (Tangarone et al., 1989). $9 \mathrm{~g}$ beta- glucanase (Sigma, USA) dissolved in $20 \mathrm{ml}$ Citrate-Phosphate buffer $(\mathrm{pH}=4.8)$ and sprayed the solution on dried food by water sprayer.

\section{Feeding trial}

Feedstuffs assayed for protein and gross energy content before mixing, thus formulated and stabilized by win feed nutrition software (version 2.8, Cambridge University, UK). Although nutrient requirements of carp are well documented, we preferred to use the most reliable reference (Nutrition NRCCoA, 1993). The feed formulation is given in Table 1. 
Table 2 . Blood biochemical characteristics of common carp.

\begin{tabular}{ccccccc}
\hline \multirow{2}{*}{$\begin{array}{c}\text { Treatment } \\
(\%)\end{array}$} & $\begin{array}{c}\text { Sugar } \\
(\mathbf{m g} / \mathbf{d l})\end{array}$ & $\begin{array}{c}\text { Uric acid } \mathbf{( m g} / \\
\mathbf{d l})\end{array}$ & $\begin{array}{c}\text { Cholesterol } \\
(\mathbf{m g} / \mathbf{d l})\end{array}$ & $\begin{array}{c}\text { Triglycerides } \\
(\mathbf{m g} / \mathbf{d l})\end{array}$ & $\begin{array}{c}\text { Total protein } \\
(\mathbf{g} / \mathbf{~ d l})\end{array}$ & $\begin{array}{c}\text { Urea } \\
(\mathbf{m g} / \mathbf{d l})\end{array}$ \\
\hline 0 & $82.33^{\mathrm{c}}$ & $0.525^{\mathrm{a}}$ & $162^{\mathrm{b}}$ & $305^{\mathrm{c}}$ & $3.5^{\mathrm{a}}$ & $7^{\mathrm{a}}$ \\
0.1 & $100^{\mathrm{a}}$ & $0.36^{\mathrm{c}}$ & $180^{\mathrm{a}}$ & $350^{\mathrm{a}}$ & $3.26^{\mathrm{c}}$ & $6.76^{\mathrm{a}}$ \\
0.5 & $91.66^{\mathrm{b}}$ & $0.4^{\mathrm{b}}$ & $169^{\mathrm{b}}$ & $338^{\mathrm{b}}$ & $3.36^{\mathrm{b}}$ & $7^{\mathrm{a}}$ \\
\hline
\end{tabular}

Means in the same row with superscripts of different letters differ significantly at $p<0.05$.

Table 3. Blood hematological characteristics of common carp.

\begin{tabular}{|c|c|c|c|c|}
\hline \multirow{2}{*}{ Treatment (\%) } & \multicolumn{4}{|c|}{ Parameter } \\
\hline & WBC (mil/ $/ \mathrm{ll})$ & RBC (mil/ $/ \mu \mathrm{l})$ & Hemoglobin (g/dl) & Hematocrit (\%) \\
\hline 0 & $6050^{c}$ & $1.39^{\mathrm{b}}$ & $9.75^{\mathrm{b}}$ & $29.28^{c}$ \\
\hline 0.1 & $6533^{b}$ & $1.41^{\mathrm{b}}$ & $10.1^{\mathrm{b}}$ & $30.13^{b}$ \\
\hline 0.5 & $6900^{a}$ & $1.43^{\mathrm{a}}$ & $10.43^{\mathrm{a}}$ & $31.3^{\mathrm{a}}$ \\
\hline
\end{tabular}

Means in the same row with superscripts of different letters differ significantly at $p<0.05$.

collecting into $2 \mathrm{ml}$ tubes containing the anticoagulant K2EDTA (50 $\mu \mathrm{l} \mathrm{ml}{ }^{-1}$ blood) for CBC and $2 \mathrm{ml}$ tubes without anticoagulant agent employed for biochemical analyses. As in mammalian samples, glucose determinations are most useful when performed on serum separated from cellular elements shortly after sampling. If more than 30 min to an hour is required to get whole blood sample back to the laboratory and processed, fluoride anticoagulant needs to be used to slow glycolysis, but also other enzymatic processes in the serum and in test reagents used in automatic serum analyzer (Stoskopf, 1993). Blood samples were imediately centrifuged at $12850 \mathrm{~g}$ and the plasma was seperated (Stone et al., 2003) All blood samples were assayd by Elan auto-analyser (Ependorf, Germany) for biochemical analyse. Glucose assayed by glucose oxidase method, urea by urease assay, uric acid by Gochman and Schmitz's enzymatic method, cholestrol by cholestrol oxidase method, trygelycerids by gelycerophosphat dehydrogenase enzymatic method and total protein by Biuret method assayd in triplicate and $\mathrm{CBC}$ assay performed according to official methods (AOAC, 2002).

\section{Analytical procedure}

Data analyzed by SPSS18 software. All data from experiments were subjected to one way ANOVA and significant differences among the means were determined by using Duncan's multiplerange test at $p<0.05$.

\section{RESULTS}

As shown, enzyme application in diets affected the biochemical (Table 2) and blood hematological parameters (Table 3). It is obvious that enzyme application at the level of $0.1 \%$ affected the biochemical characteristics such as glucose, uric acid, triglycerides and total protein significantly $(\mathrm{P}<0.05)$. Total protein was higher in control group than enzyme levels but the difference between enzyme treatments was not significant $(P>0.05)$. Urea had no significant difference. In biochemical parameters uric acid in control group was higher than enzyme treatments and even in urea significantly but not in latest one $(P<0.05)$. Cholesterol showed the same values between $0.5 \%$ enzyme treatment and control group but cholesterol level in $0.1 \%$ enzyme treatment was higher than other groups $(P<0.05)$. Cholesterol and triglycerides were higher in $0.1 \%$ enzyme level $(P<0.05)$ (Table 2$)$.

In hematological parameters, enzyme addition in $0.5 \%$ level almost affected all parameters significantly $(P<0.05)$ and then $0.1 \%$ level was in second place in balance with control group (Table 3).

\section{DISCUSSION}

Enzyme addition in monogastric animals like fishes would be very useful due to improving nutrient digestibility in at least 2 ways: (1) by supplying enzymes that animal cannot produce in sufficient quantity by itself, or (2) animal may produce enzyme itself but this exogenous enzyme would reduce the secretion of endogenous enzyme (Hajati, 2010).

According to deficiency of studies focused on enzyme applying in fishes, this study is being compared with other monogastric animals like pigs and poultry.

There is no difference between these animals except the energy content of diets that is high in terrestrial animals because of keeping blood warm and consequence reactions that need more energy to perform; For example energy requirement for chicks are 5 time than 
fishes and shrimps (Tacon, 1987).

\section{Glucose}

Glucose is probably the most studied of the non-enzymatic and non-protein components of fish serum Glucose values tend to increase with increased age in fish (Stoskopf, 1993). The inclusion of NSPs in the basic. diet of monogastric animals including fish has been reported to delay the intestinal absorption of glucose (Sinha et al., 2011). Beta- glucans basically consist of glucose residues joined by beta (1-3) and beta (1-4) linkages. Beta- glucanase acts on these linkages and glucose will be the final product of these reactions (Choct, 1997). According to results, enzyme supplementation at level of $0.1 \%$ showed the higher value between other treatments (Table 2). These results were incompatible with Oğuz et al. (2011) who reported that enzyme application did not affect glucose but were compatible by Yuan et al. (2008) results who reported that enzyme inclusion in levels of 180 and 360 mg. $\mathrm{kg}^{-1}$ significantly $(\mathrm{P}<0.05)$ increased the amount of blood sugar due to breaking the NSPs to small residues of glucose. Ao et al. (2010) reported that glucose increased according to Endopower (contain 300 unit. $\mathrm{g}^{-1}$ xylanase activity and 220 unit. $\mathrm{g}^{-1}$ beta-glucanase activity) addition at the level of $0.1 \%$ and NSPase (7 unit.g $^{-1}$ of $\alpha-1,6$-beta-galactosidase and 22 unit.g ${ }^{-1}$ of beta- 1,4-mannanase) addition at the level of $0.2 \%$. Resulted data from this experiment was compatible with Ao et al. (2010) too.

\section{Cholesterol and triglycerides}

Cholesterol levels can indicate disorders of lipid and lipoprotein metabolism and liver function which contribute to the decreased cholesterol levels (Smolowitz et al., 1998). Increasing the NSP content in the diet of monogastric animals has been reported to decrease the utilization of lipids.

Increase in digesta viscosity caused by intake of an NSP-containing diet has been shown to affect emulsification negatively, and to reduce lipolysis (Sinha et al., 2011).

One of the best reasons for high amount of cholesterol is due to high performance of enzyme at the level of $0.1 \%$ and improvement of emulsification. Present results was compatible with the studies of Mancini and Parillo (1991) and Hajati (2010) who reported that enzyme application increased the cholesterol level and was incompatible with Kermanshahi (2006) and Oğuz et al. (2011) who reported that enzyme application did not affect the cholesterol level. Oğuz et al. (2011) reported that enzyme application decreased the triglycerides. Kermanshahi (2006a) reported that enzyme applying itself in laying hens diet could not affect the triglyceride but the interaction between enzyme and dried barberry fruit and turmeric rhizome powder affected both hematocrit value and triglyceride significantly. Enzyme addition could not affect total cholesterol either.

\section{Uric acid}

In most monogastric animals, we should take care of nucleic acid supplies. For example, Hajati (2010) reported that enzyme addition in broiler chicks decreased the uric acids due to nutrient digestibility improvement. Uric acid formed by fish from exogenous and endogenous purine nucleotides and by catabolism of protein via purines. It is converted in the liver, and to lesser extent in the kidney, to urea for excretion by the gills (Stoskopf, 1993). Carbohydrate excessive concentration leads to uric acid production which deplete to urinary system (Stone, 2003). As seen in this study enzyme applying in $0.1 \%$ level could decrease the uric acid significantly than other treatments $(p<0.05)$; the main reason for this phenomenon is due to blood sugar production. Hajati (2010) reported that uric acid in young chickens decreased on 22th and 44th of experiment which is not compatible by this study.

\section{Urea}

Inclusion of NSPs in monogastric animal feeds lead in amino acid metabolism reduction. As NSPs take part in animal nutrition, the viscosity of digesta increases and proteins digestion occurs by some deficiencies and $\mathrm{N}$ secretion happens that reveals as excess in urea secretion (Sinha et al., 2011). Most urea in fishes is produced by the liver, but urea passes rapidly though most internal membranes and is consequently found in all fish tissues. It is excreted in small quantity in relation to total nitrogen excretion, primarily by the gills (Stoskopf, 1993). Borg et al. (1987) that blood urea can reflect the state of protein metabolism and amino acid balance and said that when blood urea is low, the balance of amino acids balance is good (Borg et al., 1987). Even though the blood urea is lowest than others but this difference is not analytically significant $(P>0.05)$. Another reason to describe the blood decrease refers to protein sparing role of carbohydrates. When carbohydrate is well utilized, animal body uses the carbohydrate for construction of some parts such as nervous system and prevents to amino acid catabolism. These amino acids will be employed for development of other parts of animal body. (Stone, 2003) Yuan et al. (2008) found that blood urea content in broilers fed enzyme treated diets at the levels of $0 \mathrm{mg} / \mathrm{kg}$ (control) and $720 \mathrm{mg} / \mathrm{kg}$ were so higher and in $360 \mathrm{mg} / \mathrm{kg}$ was lower values $(\mathrm{p}<0.05)$. This is because of best feed utilization in $360 \mathrm{mg} / \mathrm{kg}$ treatment. Ao et al. (2010) reported that inclusion of multi enzyme (Endopower) containing 300 unit/g xylanase activity and 220 unit/g beta- glucanase activity in $0.1 \%$ level increased 
the amount of blood urea in piglets. Results of this study were compatible with the results of Yuan et al. (2008) and were in compatible with Ao et al. (2010).

\section{Total protein}

Alternate cause of low total proteins include decreased intake through starvation, decreased synthesis due to hepatic dysfunction, increased capillary permeability for plasma proteins, or degradation of protein by proteolytic enzymes released from endothelial cells destroyed by viruses or bacteria (Stoskopf, 1993). As mentioned above, carbohydrates play an important role in protein sparing. Decrease in plasma protein probably reflects the accumulation of amino acids and dissolved proteins in animal tissues.

\section{Hematological parameters}

It is known that CBC parameters dependent on age of fish (Stoskopf, 1993); but we saw in this study that enzyme could affect the hematocrit value due to WBCs and RBCs, hemoglobin, hematocrit values due to metabolism improvement that occurred by enzyme addition. One of most powerful hypothesis about RBCs increase is due to beta- glucan existence. As revealed by Brattgjerd et al. (1994) on Atlantic salmon (Salmo salar), Selvaraj et al. (2005) on common carp (C. carpio) and Sung et al. (1994) on tiger shrimp (Penaeus monodon), beta- glucan (specially beta 1-3 glucan) is an immunity stimulant for animals (Sinha et al., 2011). So glucan residues would cause the WBCs and maybe RBCs production in this experiment.

\section{CONCLUSION AND PROPOSAL IDEAS}

The study suggest that beta- glucanase addition in aquafeed based on barley can be useful for fish health and maybe as immunity stimulator and supplemental tool for drug addiction. Enzyme addition would be more useful in seasons when animal need more energy for mobility or reproduction. There are a few works on enzyme addition for animals but there are fewer studies about fishes. Even study on effects of enzyme addition on reproduction tissues would be interesting.

\section{ACKNOWLEDGMENTS}

Authors would like to extend a special thanks to Dr. Abd Almajid Hajimoradlou and Dr. Ali Akbar Hedayati for the particular guidance and other friends for their cooperation in this project.

\section{REFERENCES}

Ao X, Meng Q, Yan L, Kim H, Hong S, Cho J, Kim I (2010). Effects of Non-starch Polysaccharide-degrading Enzymes on Nutrient Digestibility, Growth Performance and Blood Profiles of Growing Pigs Fed a Diet Based on Corn and Soybean Meal. Asian-australasian J.Ani Sci. 23(12): 1632-1638.

AOAC (2002). Official methods of analysis. Association of Official Analytical Chemists. Arlington,VA, USA.,

Bach Knudsen K, Eggum B, Jacobsen I (1987a). Nutritive value of Danish-grown barley varieties, II, Effect of carbohydrate composition on digestibility of energy and protein. J. Cereal Sci. 6(2):187-195.

Bach Knudsen K, Aman P, Eggum B (1987b). Nutritive value of Danishgrown barley varieties, I, Carbohydrates and other major constituents. J. Cereal Sci. 6(2):173-186.

Bahramsari N, Zamani MR, Matlabi M (2007). $\beta$-1,3-glucanase production in Trichoderma isolates. Iranian. J Biol. 18(3):261-271.

Bogut I, Milakovic Z, Bukvic Z, Brkic S, Zimmer R (1998). Influence of probiotic (Streptococcusfaecium M74) on growth and content of intestinal microflora in carp (Cyprinuscarpio). Czech J. Anim. Sci.UZPI. 43(5):231-235.

Borg B, Libal G, Wahlstrom R (1987). Tryptophan and threonine requirements of young pigs and their effects on serum calcium, phosphorus and zinc concentrations. J. Anim. Sci. 64(4):1070-1078.

Brattgjerd S, Evensen O, Lauve A (1994). Effect of injected yeast glucan on the activity of macrophages in Atlantic salmon (Salmosalar .,L) as evaluated by in vitro hydrogen peroxide production and phagocytic capacity. Immunology 83(2):288-296.

Campbell GL, Classen HL, Ballance GM (1986). Gamma irradiation treatment of cereal grains for chick diets. J. Nutr. 116(4):560-569.

Choct M (1997). Feed non-starch polysaccharides: chemical structures and nutritional significance. Feed Milling Int. 191(6):13-26.

Colowick SP, Kaplan NO (1955). Preparation and Assay of Enzymes. In: Colowick SP, Kaplan NO (eds) Preparation and Assay of Enzymes: Academic Press INC. pp. 136-146.

Fry RE, Allred JB, Jensen LS, McGinnis J (1958). Influence of enzyme supplementation and water treatment on the nutritional value of different grains for poults. Poultry Sci. 37(2):372-375.

Graham H, Löwgren W, Pettersson D, Åm P (1988). Effect of enzyme supplementation on digestion of a barley/pollard based pig diet. Nutr. Rep. Int. 38(5):1073-1079.

Hajati H (2010). Effects of enzyme supplementation on performance, carcass characteristics, carcass composition and some blood parameters of broiler chicken. Am. J. Anim. Veter. Sci. 5(2):155-161.

Herstad O, McNab J (1975). The effect of heat treatment and enzyme supplementation on the nutritive value of barley for broiler chicks. British Poultry Sci. 16(1):1-8.

Hesselman K, Thomke S (1982). Influence of some factors on development of viscosity in the waterextract of barley [cultivars, climate, nitrogen fertilization, beta-glucan]. Swedish. J. Agric. Res. 12(1):17-22.

Jensen MS, Bach Knudsen KE, Inborr J, Jakobsen K (1998). Effect of [beta]-glucanase supplementation on pancreatic enzyme activity and nutrient digestibility in piglets fed diets based on hulled and hulless barley varieties. Anim. Feed Sci. Technol. 72(3):329-345.

Kaiser A (1999). Increasing the utilisation of grain when fed whole to ruminants. Aust. J. Agric. Res. 50(5):737-756.

Kalia s, Kaith BS, Kaur I (2011). Natural Fibres. In: Kalia s, Kaith BS, Kaur I (eds) Natural Fibres in: springer, London. p. 758.

Kermanshahi H, Riasi A (2006). Effect of dietary dried berberis vulgaris fruit and enzyme on some blood parameters of laying hens fed wheat soybean based diets. Int. J. poultry Sci. 5(1):89-93.

Kermanshahi H, Riasi A (2006a). Effect of turmeric rhizome powder (Curcumalonga) and soluble NSP degrading enzyme on some blood parameters of laying hens. Int. J. Poult. Sci. 5(5):494-498.

Knudsen KEB (1997). Carbohydrate and lignin contents of plant materials used in animal feeding. Anim. Feed Sci. Technol. 67(4):319-338

Mancini M, Parillo M (1991). Lipid intake and atherosclerosis. Annals Nutr. Metabol. 35(1):103-108.

Mathlouthi N, Mallet S, Saulnier L, Quemener B, Larbier M (2002). Effects of xylanase and b-glucanase addition on performance, nutrient 
digestibility, and physico-chemical conditions in the small intestine contents and caecal microflora of broiler chickens fed a wheat and barley-based diet. Anim. Res. 51(5):395-406.

Nutrition NRCCoA (1993). Nutrient requirements of fish. National Academies Press, U.S.A. p.128.

Ogino C (1980). Protein requirements of carp and rainbow trout. Bulletin of the Japanese Soc. Sci. Fish. 46(3):385-388.

Oğuz M, Oğuz F, Göncüoğlu E (2011). The effect of dehulled barley on performance and some blood parameters on quails. Yüzüncü yıl Üniversitesi Veteriner Fakültesi Dergisi. 22(3):175-179.

Rowe J, Choct M, Pethick D (1999). Processing cereal grains for animal feeding. Aust. J. Agric. Res. 50(5):721-736.

Sabatier AM, Fish NM (1996). Method of analysis for feed enzymes: methodological problems. J. Appl. Poultry Res. 5(4):408-413.

Selvaraj V, Sampath K, Sekar V (2005). Administration of yeast glucan enhances survival and some non-specific and specific immune parameters in carp (Cyprinuscarpio) infected with Aeromonas hydrophila. Fish Shellfish Immunol.19(4):293-306.

Shabir S, Salim M, Rashid M (2003). Study on the feed conversion ratio (FCR) in major carp Cirrhinus mrigala fed on sunflower meal, wheat bran and maize gluten. Pak. Veter. J. 23(1):1-3.

Siddhuraju P, Becker K (2001). Preliminary nutritional evaluation of Mucuna seed meal (Mucunapruriens var. utilis) in common carp (Cyprinuscarpio L.): an assessment by growth performance and feed utilisation. Aquaculture196(1-2):105-123.

Sinha AK, Kumar V, Makkar HPS, De Boeck G, Becker K (2011). Nonstarch Polysaccharides and their role in fish Nutrition-A. Rev. Food Chem. 127(4):1409-1426.

Smolowitz R, Wadman E, Chikarmane H (1998). Pseudomonas putida infections of the oyster toadfish (Opsanustau). Biol. Bull. 195(2):229231.
Stone D, Allan G, Anderson A (2003). Carbohydrate utilization by juvenile silver perch, Bidyanus bidyanus (Mitchell). III. The protein-sparing effect of wheat starch-based carbohydrates. Aquacult. Res. 34(2): 123-134.

Stone DAJ (2003). Dietary carbohydrate utilization by fish. Rev. Fish. Sci. 11(4):337-369.

Stoskopf MK (1993). Fish medicine. WB Saunders Company. p. 882.

Sung $H$, Kou G, Song $Y$ (1994). Vibriosis resistance induced by glucan treatment in tiger shrimp(Penaeusmonodon). Fish Pathol. 29(1):1117.

Tacon AGJ (1987). The nutrition and feeding of farmed fish and shrimp; a training manual. 1: The essential nutrients.

Tangarone B, Royer J, Nakas J (1989). Purification and Characterization of an Endo-(1, 3)- $\beta$-d-Glucanase from Trichodermalongibrachiatum. Appl. Environ. Microbiol. 55(1):177184.

Yanbo W, Zirong X (2006). Effect of probiotics for common carp (Cyprinuscarpio) based on growth performance and digestive enzyme activities. Anim. Feed Sci. Technol. 127(3):283-292.

Yuan J, Yao J, Yang F, Yang X, Wan X, Han J, Wang Y, Chen X, Liu Y, Zhou Z (2008). Effects of supplementing different levels of a commercial enzyme complex on performance, nutrient availability, enzyme activity and gut morphology of broilers. Asian-Australasian. J. Anim. Sci. 21(5):692-700. 